\title{
NUTRITIONAL STATUS AND SOCIAIZATION ABILITY IN CHILDREN WITH AUTISTIC DISORDER
}

\author{
Yeni Suryaningsih 1), Eka Indah Aditia 2) \\ 1) Lecturer of Faculty of Health science University of Muhammadiyah Jember \\ 2) Student of Bachelor Nursing Programme Faculty of Health Science UM Jember \\ Corresponding e-mail : yeni@unmuhjember.ac.ld
}

\begin{abstract}
BACKGROUND : Autism is a pervasive development disorder that affects abilities in social interaction, communication and behavior. The disorder is seen before a three year old child. Children with autistic disorders have behavioral disorders called autistic behavior. Autistic behavior is classified into two types, namely excessive behavior and deficit behavior. The purpose of this study was to determine the relationship between nutritional status and socialization ability in autistic children.
\end{abstract}

SUBJECT AND METHODE : This study is a correlation study conducted with a cross sectional approach. The population in this study were 35 autistic children in SLB Bintoro. The instrument used was a questionnaire on the nutritional status of autistic children to assess nutritional status, and a Social Skills training (SST) sheet to assess the socialization skills of autistic children. Data analysis was carried out by using the Spearman Rho correlation statistical test.

RESULTS : The results showed that the results of the study using the Sperman RHO test for nutritional status on the socialization abilities of autistic children showed that a significant value of $p$ $=0.000$ because the value of $p<0.05$, there was a significant relationship between nutritional status and the ability to disseminate information on autistic children shows a very strong relationship.

DISCUSSION : Nutrition status is one factor that greatly affects the socialization capabilities of autistic children.

Key words : Nutritional Status, Socialization Skills, Autism

\section{INTRODUCTION}

Autism is a pervasive developmental disorder that affects the ability of social interaction, communication and behavior. The disorder is seen before the child is three years old. Children with autistic disorder are having behavior called autistic behavior. This behavior is classified into two types, namely excessive behavior and deficient behavior. Excessive behavior is hyperactive and tantrum behavior such aas screaming, flapping, biting, clawing, hitting and including self abuse. Deficient behavior is a behavior that cause speech disorder or lack of social behavior such as laughing or crying without a reason and daydreaming (Nurhidayati, 2015).

The data taken from Health Basic Research (Riskesdas) 2013 stated that the number of autistic patients reach 112.000 people out if 253,60 million people in Indonesia. According to the Chief of the East Java Education Office, arround 2009 in East Java there were 388 special school for children with special need with 13,150 students. There are 93 schools with children with special needs 1,478 childrean and $15 \%$ are autistic children. The preleminary study in Jember Regency 
found 60 childrean suffering from autism at school age, from 6 SLB spread across Jember Regency (Jember Regency Education Office, 2018).

Behavioral disorder in autistic children are influenced bay various factors. One of them is food, especially foods that contain gluten. This occurs because the type of protein is difficult to digest bay the body. There are some abnormalities found in gastrointestinal membrane of autistic children, which is the abnormalities of the pores and hypermeability of intestinal mucosal. Gluten in autistic children is only broken up into polypeptides. These polypeptides then absorbed into the bloodstream and circulate in the form of gluteo. The gluteo bound to receptors in the brain that affect mood and behavior so that the binding of these two substance can affect behavior disorder in autistic children. Therefore, one way to reduce behavioral disorders in children with autism, is avoiding food that contain gluten (Nurhiadayati, 2015).

Social skill training is one way that believe can improve socialization skill in autistic children. It can be thaught individually or by group. Social skill training are indicate for children with intercation difficulties, social phobia and anxiety. This training conduct to improve children's ability to interact in an environment, so that they could improve their self control, improve the ability to do activity independently or together with friend and improve interpersonal skill by training to socialize with people and environment (Landeen, 2001 : Kneisl, 2004). Walter (2011) stated that social skill training could become standart theraphy for psychiatric nursing specialist and need to be socialized to all helath service order. A good autistic nutritional status merger with social skill training are believed to improve social skill of an autistic children significantly.

The preleminary study has been done in May 2019. The result show that most parent of autistic childrean are not pay attention about the food consume by their children. It should appropriate with the right nutritional status according to physician's advice, so that it could affect socialization ability in autistic children.

\section{METHODE}

This study is a correlation study conducted with a cross sectional approach. The population in this study were 35 autistic children in SLB Bintoro. The instrument used was a questionnaire on the nutritional status of autistic children to assess nutritional status, and a Social Skills training (SST) sheet to assess the socialization skills of autistic children. Data analysis was carried out by using the Spearman Rho correlation statistical test.

\section{RESULTS AND DISCUSSION}

Data collection has been done at May 2019 and involving 35 autistic children in SLB - B autism TPA Jember. The results are showed in table 1.

Tabel 1. General Characteristic of Respondents (Source: Primary Data Research, 2019)

\begin{tabular}{llll}
\hline Characteristic & Amount & Procentage \\
\hline Age & & \\
& $4-9$ years old & 4 & 11,4 \\
$10-14$ years old & 13 & 37,1 \\
$15-19$ years old & 15 & 42,9 \\
\hline
\end{tabular}



$>20$ years old
3
8,6

Gender

$\begin{array}{lll}\text { Male } & 28 & 80,0 \\ \text { Female } & 7 & 20,0\end{array}$

Nutritional status

Good

23

65,7

Not good

12

34,3

Autistic level

$\begin{array}{lll}\text { Mild } & 17 & 48,6 \\ \text { Moderate } & 11 & 31,4 \\ \text { Severe } & 7 & 20,0\end{array}$

This research is done at Jun 2019. There were 35 respondents consist of 28 male and 7 female students. Respondent with good nutritonal status counted 23 children and 12 children are not. Parents stated that they do ot provide good nutrition is because of ignorance about gluten and some are of the opinion because there is no effect whatsoever. Some parents who have given a gluten free diet claim that there is a difference if they are on gluten diet, the children are more communicable and not do repetitive movement.

Gluten considered as a toxic since the body of an autistic person do not produce enzyme to digest the protein. Undigestabel protein then turned into chemical component called opiod which is like morfin, opium and heroin which work as a toxic which is interfere brain function, immunity and behavioral disorder (Abata, 2014).

Removing food that contain wheat will reduce the intake of vitamin and minerals in child's body. That is why children need to be given enough vitamin and mineral so that they would grow healhty. Vitamin and minerals should be provide under supervision of professional (physician or nutritionist) and if its not done then the metabolic process of digestion will be disrupted (Nugraheni, 2008).

Autistic behavior is a special behavior disorder of an autistic children. Those behavior include hyperactivity (unpurposed movement), inability to maintain eye contact with others, does not repond if called, unreasonable crying or laughing and some other indicator of special behavior. Some respondents of this research are found to have behavioral disorder whish is $20 \%$ respondents are having severe autism, 31\% respondents are having moderate autism and $48,6 \%$ respondents are having mild autism level. The reduction of autistic behavior commonly in form of reduction of hyperactive intensity to a subject and subject ability in doing an instruction from theraphyst, ability to concentrate and starting to put up words to speak.

Some factors could interfere autistic behavior such as therapy intensity, methode of therapy, parent and family involvement and diet therapy. According to results of questionaire given to subject's parents, most of the parents claim that there a correlationship between autistic behavior and child's eating habit. Behavioral disorder such as hyperactivity are believed to decrease since the parent reduce the frequency in giving martabak or sweet martabak that contain flour. 
Dietary pattern of an autistic child must contain a number of nutrient, especially high in carbohydrate, protein, and calcium to fulfill needs during growth and development. the experts agree that people with autism must have good nutritional status by doing gluten diet. Gluten diet is believe could improve digestive disorders and also reducing symptoms or improve behavior of an autistic child. Even gluten and protein came from the same class, gluten are derived from wheat such as flour wheat, oat danbarley (Seroussi, 2004).

Tabel 2. Analysis Behavior and Gluten Consumption

\begin{tabular}{|c|c|c|c|c|}
\hline & & & Free gluten & Perilakuanak \\
\hline \multirow[t]{2}{*}{ Spearman's rho } & $\begin{array}{l}\text { Free } \\
\text { Gluten }\end{array}$ & $\begin{array}{l}\text { Koefisien Korelasi } \\
\text { Sig. (2-tailed) } \\
\text { N }\end{array}$ & $\begin{array}{l}1.000 \\
35\end{array}$ & $\begin{array}{l}.653^{* *} \\
.0,00 \\
35\end{array}$ \\
\hline & $\begin{array}{l}\text { Perilaku } \\
\text { AnakAutis }\end{array}$ & $\begin{array}{l}\text { Koefisien Korelasi } \\
\text { Sig. (2-tailed) } \\
\text { N }\end{array}$ & $\begin{array}{l}.653^{* *} \\
.000 \\
35\end{array}$ & $\begin{array}{l}1.000 \\
35\end{array}$ \\
\hline
\end{tabular}

Table 3. Coefficient Value

\begin{tabular}{ll}
\hline Coefficient & Correlational Power \\
\hline 0,00 & No correlationship \\
$0,01-0,09$ & Less correlationship \\
$0,10-0,29$ & Weak correlationship \\
$0,30-0,49$ & Moderate relationship \\
$0,50-0,69$ & Strong relationship \\
$0,70-0,89$ & Very strong correlationship \\
$>0,90$ & Near perfect correlationship \\
\hline
\end{tabular}

According to the table Spearman RangE (Rho) test show that the analysis from 35 respondent produce $p$ value $0,000<0,05$. It mean $\mathrm{H} 1$ accepted, there is a correlationship between nutritional status and socialization ability of autistic children in SLB B autism TPA Jember. Coefficient value of these two variable is 0,653 which mean show a very strong correlationship.

This research produce $p$ value $<0,05$ mean hypothesis accepted. In the other words there are correlationship between nutritioanl status and social ability of autistic childrenin SLB B Autism TPA Jember. Correlation coefficient value is 0.653 mean these two variable has very strong correlationship. 
One of the action that can be done to prevent hyperactive bahavior in autistic children is by doing regulation of food selection. Food is a matter that must be considered for people with autism. Their food commonly same as healthy children in general, which is healthy and meets balanced nutrition (Kusumayanti, 2011).

Selection of foods that are in accordance with the diet must be given appropriately in order to prevent malnutrition in autistic children. Children should not be allowed to choose their own food. Autistic children must be given special diet according to symptoms experienced. Autistic children is also must be avoid food that contain monosodium glutamate and artificial food coloring. This kind of food could lead to changing of behavior and emotional of an autistic person after consume food that contain gluten. In the other hand some food contain artificial food coloring could destroy DNA that can lead to genetical mutation and disturbing the function of brain and nervus. Artificial food coloring also can cause allergies in autistic children (Ramadayanti, 2013).

Analytical statistic using Spearman rho about nutritional status to social ability of an autistic children showing significant $p$ value 0.000 . since $p$ value $<0.05$ it can be stated that there are significant influence between nutritional status to social ability of an autistic children. This result is in line with the research conduct by Rifmie Arfiriana Pratiwi (2013) which is stated that there are correlationship between the frequency of consuming food free gluten and free cassein with behavioral changing af an autistic person. The more they consume food containing gluten and cassein the more frequent they will have behavioral changing. It is all happen due to incomplete breakdown of protein contained in gluten and casein. Gluten and casein are part of short chain amino acids called peptide. Normally peptides are absorb in a litlle amount by the body then eliminate through feses. And this metabolism are not happen in autistical person.

Hypermeability of intestinal mucosa in autistical person causing this peptides to increase. Some are absorbed into the circulation and some are absorbed to the brain. Peptides that travel to the brain are attach to opioid receptors in the brain and change it functions like morphine. Gluten peptides will form glutemorphin and gliadimorphin while casein peptide will change into caseomorphin. The two substance will affect central nervus system so that it can lead to behavioral disorder. This statement is in accordance with observations that have been carried out in this study that autsitic person who have low frequency habits in consuming foods containing gluten and casein will have more directed behavioral changes compared to them who have high frequency in consuming food that contain gluten and casein. Some of the bhavioral changes including the children become more calm, easily given instructionat at therapy, not easy to cry or angry.

\section{CONCLUSION AND RECOMMENDATION}

According to analytical statistic using Spearman Rho test about nutritional status to social ability of an autistic children showing significant $p$ value 0.000 . since $p$ value $<0.05$ it can be stated that there are significant influence between nutritional status to social ability of an autistic children. Corelation coefficient value is 0.653 show a significant correlationship

From the result above some recommendation that coul be given as follow : SLB B autism TPA Jember should maintain good nutritional status by doing free gluten diet and involving family to 
improve the knowledge of the client and family about autistic chlidren's nutritional status so that they could have good socialization ability.

The family of an autistic children shoud have a full commitment in free gluten diet programme so that the children will have a good nutritional status as specified so that their condition is controlled and their social ability will improve.

\section{REFERENCE}

Abata, QA. 2014. Alergi Makanan. JawaTimur:Yayasan PP Al-Furqon.

Dinas Pendidikan Kabupaten Jember. (2015). Data anak penderita autis di Kabupaten Jember.

Kneisl, C.R., Wilson, H.S. \& Trigoboff, E. (2004). Contemporary psychiatric mental health nursing. New Jersey : Pearson Prentice Hall.

Ladd, G. W., \& Mize, J. (1983). A cognitive-social learning model of social skill training. Journal of Psychological Review, 90(2), 127-157.

Maag (2006). Social skills training for students with emotional and behavioral disorders a review of review studi Meta-analysis. Journal of Behavioral Disorder 32(1), 5-17

National Institude of Mental Disorder. (2007). Autism spectrum disorder. pervasive Developmental Disorder. Department and Mental and Human Services

Nugraheni, S, A., 2008, Efektivitas Intervensi Diet Bebas Gluten Terhadap Perubahan Perilaku Anak Autis. Semarang: Pustaka Rizki Putra.

Nurhidayati, Zygawindi. 2015.Pengaruh Pola Konsumsi Makanan Bebas Gluten Bebas Kasein dengan Gangguan Perilaku pada Anak Autistik.Jurnal Fakultas Kedokteran Universitas Lampung Volume 4 nomer 7

Nursalam. 2013. Konsep dan Penerapan Metodologi Penelitian IImu Keperawatan.Edisi ketiga. Jakarta: SalembaMedika.

Rose. 2010. Anak cacat bukan kiamat.Katahati, Yogyakarta

Seroussi. 2004. Asupan Gluten dan Casein pada Anak Autisme : Jakarta

Stuart, G.W. 2011. Principles and practice of psychiatric nursing 9th Edition. St Louis: Mosby Elsevier Stuart, G.W \& laraia, M.T. (2005). Principle and practice of psichiatric nursing. (8 $8^{\text {th }}$ ed). Philadelphia, USA: Mosby, Inc

Thams-Little dan Hordgrafer (1996). Early communication development in children with Rett Syndrom. Original Article: Elsevier

Townsend, M.C (2009). Psychiatric mental helath nursing (6 $\left.6^{\text {th ed }}\right)$. Philadelphia: F.A. Davis Company Walter (2011). Penerapan trapi social skill training pada klien isolasi sosial dengan pendekatan teori hubungan interpersonal Peplau di Rumah Sakit Marzoeki Mahdi Bogor. Universitas Indonesia, Jakarta

Yusuf. (2014). Psikologi perkembangan anak dan remaja. Bandung. PT Remaja Rosdakarya 